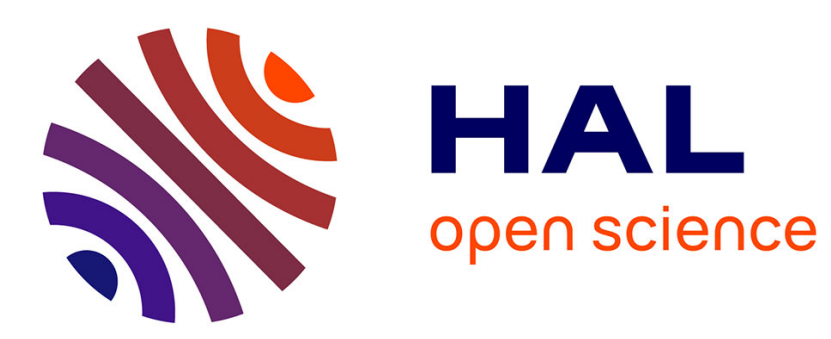

\title{
The glocalization of responsible investment: Contextualization work in France and Quebec
}

Jean-Pascal Gond, Eva Boxenbaum

\section{To cite this version:}

Jean-Pascal Gond, Eva Boxenbaum. The glocalization of responsible investment: Contextualization work in France and Quebec. Journal of Business Ethics, 2013, 115 (4), pp.707-721. hal-00870436

\section{HAL Id: hal-00870436 \\ https:/ /hal-mines-paristech.archives-ouvertes.fr/hal-00870436}

Submitted on 14 Jan 2015

HAL is a multi-disciplinary open access archive for the deposit and dissemination of scientific research documents, whether they are published or not. The documents may come from teaching and research institutions in France or abroad, or from public or private research centers.
L'archive ouverte pluridisciplinaire HAL, est destinée au dépôt et à la diffusion de documents scientifiques de niveau recherche, publiés ou non, émanant des établissements d'enseignement et de recherche français ou étrangers, des laboratoires publics ou privés. 
THE GLOCALIZATION OF RESPONSIBLE INVESTMENT:

CONTEXTUALIZATION WORK IN FRANCE AND QUEBEC

\author{
Jean-Pascal Gond \\ Cass Business School \\ City University London \\ 106, Bunhill Row, London, UK \\ EC1Y 8TZ \\ $\mathrm{T}+44(0) 2070400980$ \\ $\mathrm{F}+44(0) 2070408328$ \\ jean-pascal.gond.1@city.ac.uk
}

\author{
Eva Boxenbaum \\ MINES ParisTech \\ 60, Boulevard Saint-Michel \\ 75272 PARIS cedex 06, France \\ eva.boxenbaum@mines-paristech.fr \\ $\&$ \\ Copenhagen Business School \\ Kilevej 14A, 2000 Frederiksberg, Denmark
}

Manuscript accepted for publication in the Journal of Business Ethics 


\title{
THE GLOCALIZATION OF RESPONSIBLE INVESTMENT: CONTEXTUALIZATION WORK IN FRANCE AND QUEBEC
}

\begin{abstract}
This study investigates the institutional work that underlies the diffusion of responsible investment (RI) and enhances its adaptation to local settings. Building on institutional and actor-network theory, we advance the concept of contextualization work to describe the institutional work that sustains RI glocalization. Empirical data from two case studies highlight how entrepreneurial actors imported the notion of responsible investment (RI) from the US to France and Québec. Our findings uncover three types of contextualization work filtering, repurposing, and coupling - that sustain RI glocalization, and show how actors employed them in both settings to overcome the lack of technical, cultural or political fit between the imported practice and their local context. Our results explain how divergent glocalized versions of RI are developed and adapted through contextualization work. Lastly, we discuss how our repertoire of contextualization work can account for local forms of a global concept and the uneven pattern of its diffusion.
\end{abstract}

\section{Key-words}

Contextualization Work - Diffusion - Glocalization - Institutional Work - Responsible Investment 


\section{THE GLOCALIZATION OF RESPONSIBLE INVESTMENT: CONTEXTUALIZATION WORK IN FRANCE AND QUEBEC}

'In fact, the trajectory of a project depends not on the context but on the people who do the work of contextualizing.' (Latour 1996, p.150)

Although Responsible Investment (RI) has become a globally diffused phenomenon (Louche and Lydenberg 2006), it is also recognized as being highly heterogeneous (Sandberg et al. 2009), and as being embedded in the local cultural, religious and political contexts in which it is practiced (Bengtsson 2008; Lozano, Albareda and Balaguer 2006). But how has RI spread globally while maintaining, and even increasing, its cross-national diversity? How is RI reshaped as a result of being embedded in different contexts?

To address these questions, we focus on the process of 'glocalization', whereby a practice undergoes local transformation at the same time as it diffuses globally (Latour 1993; Robertson 1992). Our objective is to identify and theorize the activities involved in the glocalization of RI and, in so doing, to provide an explanation for both the global diffusion of $\mathrm{RI}$ and the maintenance of its diversity. Ultimately, we aim to shed light on micro-processes that contribute to transforming RI and to advance the conceptualization of glocalization; more precisely, we show how material and symbolic dimensions are combined in micro-level glocalization processes.

Conceptually, our investigation of the process of RI glocalization builds on recent developments in the literature on 'institutional work', which pertains to creating, maintaining and disrupting institutions (Lawrence and Suddaby 2006). The concept of institutional work concerns the exploration of how actors address the potential lack of technical, cultural, or political 'fit' between the practice and its new local context (Ansari et al. 2010; Perkmann and Spicer 2008). Prior studies in this field have somewhat neglected the capacity of actors to purposefully select elements of the institutional context within which they operate so as to deliberately 'create' a new context for an imported practice. To address this gap, we draw on 
actor-network theory, notably on the work of Latour (1996, p.133), who argues that actors' purposive activities provide - or sometimes fail to provide - a new business practice with its context. We propose to combine institutional work and actor-network theory through the concept of 'contextualization work', which we define as the specific institutional work involved in achieving a technical, cultural, or political 'fit' as part of the process of glocalization.

To empirically analyze the work of contextualization that underpins the global diffusion of RI, we conducted two case studies focusing on how actors 'imported' elements from US RI practice into France and Québec. Our analysis illuminates commonalities in how these individuals identified, selected, mobilized, and combined foreign and local RI components in their efforts to contextualize and thus fit RI to their respective societies. We suggest these commonalities make up a repertoire of work by which actors contextualize RI; this repertoire is composed of three types of work - filtering, repurposing, and coupling - via which individuals engage creatively with local, foreign, and sometimes global elements to contextualize the globally diffusing RI business practice.

In clarifying the contextualization work that leads to the glocalization of RI, our paper makes a threefold theoretical contribution. First, in uncovering the work of contextualization that allows RI to spread across different institutional contexts, our analysis illuminates why the practice of RI can simultaneously maintain strong local specificities while becoming more diffused on a global scale. Second, our results explain how actors engage in micro-level activities that shape the transformation of RI practices in a given social context. We recognize the unpredictable_nature of these transformations. Indeed, our two cases suggest that a similar type of contextualization work can trigger divergent outcomes in terms of 'exported' RI practices. Notably, our results show that actors influence the adaptation of RI through their peculiar understanding of the imported RI practice and their decisions to rely on 
a specific combination of types of contextualization work. Finally, by uncovering how actors combine material and symbolic dimensions through their contextualization work, we develop a consolidated repertoire of contextualization work that could potentially be applied to the diffusion of other practices.

\section{THEORIZING GLOCALIZATION: CONTEXTUALIZATION WORK}

\section{Prior Approaches to Glocalization}

Politico-economic View: Glocalization as Institutional Reproduction. A first stream of glocalization research argues that politico-economic institutions in the host society shape imported business practices in ways that mirror those institutions (Casper and Hancké 1999; Djelic and Quack 2003; Fiss and Zajac 2004; Jacoby 2000). Informed by 'varieties of capitalism' (Hall and Soskice 2001) or ‘national business system' (Whitley 1999) frameworks, this line of research argues that 'the systemic character of institutions in advanced industrial societies forces institutional innovations and transfers to be organized so that they fit the broader institutional order' (Casper and Hancké 1999, p.963). National institutions, particularly market and political structures, are thus seen as shaping foreign business practices (Jackson and Deeg 2008).

According to this macro-social perspective, glocalization unfolds with little conscious or creative engagement on the part of individuals, who tend merely to 'mechanically' reproduce the local institutional context. However, actors outside state structures may sponsor or pull in a foreign practice once they identify unexpected opportunities that suit their own material or moral ends (Jacoby 2000, pp.20-21). Using their power and the resources available to them (Casper and Hancké 1999, p.962), actors may engage in 'selective emulation' and 'choose not to adopt certain features of the original model because they conflict with local patterns' (Westney 1987, p.27); alternatively, actors may use 
'hybridization' to combine a foreign practice with local elements (Pieterse 1994).

Cultural View: Glocalization as Interpretative Translation. A second approach to glocalization emphasizes the role of collective cognition in the process. This line of work builds on organizational institutionalism and draws attention to the 'taken-for-granted' ideas that implicitly govern interactions in the host society (Greenwood, Oliver, Suddaby and Sahlin 2008). Dominant ideas shape the meaning of globally diffused business practices so that they reflect the beliefs, norms, laws, and values that characterize the host society. Imported business practices must be adapted because they must reflect local ideation if they are to make sense to the host society (Biggart and Guillen 1999, p.726), or they risk being considered immoral, irrational or irrelevant and therefore discarded (Biggart and Beamish 2003, p.448).

Empirical studies confirm that ideational adaptation facilitates the local adoption of imported practices (Boxenbaum 2006; Frenkel 2005; Westney 1987). Such adaptations are part of a range of legitimation strategies which focus on the symbolic, discursive and rhetorical rather than on the socio-material dimensions (Özen and Berkman, 2007; Vaara, Tienari and Laurila, 2006). According to this perspective, practices can remain materially identical but need to be symbolically repackaged to fit the new context. Illustrating this approach, Kerstin Sahlin-Anderson (1996) suggests that actors mobilize different 'editing rules' that facilitate the export of a local practice to enable individuals to translate a contextspecific practice into one which is a more widely appealing and applicable in the host society. Socio-technical View: Glocalization as Socio-material Adaption. A third perspective on glocalization is inspired by actor-network theory and assigns primary importance to the material transformations of practices during their diffusion (Ansari et al. 2010; Latour 2005). Research conducted from this perspective focuses on how actors creatively transform globally diffusing business practices in the 'to adopt is to adapt' spirit (Akrich et al. 2002, 
p.207). This research,highlights the processes via which material objects and concrete practices are transformed to fit new contexts (Ansari et al. 2010). Accordingly, glocalization can be described as an act of "translation" in the actor-network theory sense of the term (Latour 2005), that is, a process that involves the transformation of a diffused object or the materialization of a diffused concept. Czarniawska and Joerges' (1996) description of the 'travel of ideas' captures the socio-material nature of glocalization, distinguishing it from interpretative translation, which solely involves symbolic, rhetorical or discursive changes. Limitation of Prior Perspectives. While all three of these prior perspectives account for important dimensions of glocalization, each one provides only a partial explanation of how actors engage political, cultural, or socio-technical factors in their glocalization practices. For instance, cultural perspectives highlight sense-making and the symbolic re-packaging of unchanged practices (Sahlin-Andersson 1996), whereas socio-technical views emphasize the material adaptation and transformation of a practice (Akrich et al. 2002). Glocalization may require both kinds of changes. In fact, as Ansari et al. (2010) suggest, actors may need to engage the full range of political, cultural and technical dimensions of the new context to diffuse a business practice successfully. We do not yet know how these three dimensions interact during glocalization. This limitation calls for a consolidated approach to glocalization, which integrates insights from these three perspectives, and offers a template for action that addresses the multiple dimensions of glocalization. We propose to conceptualize this integration as contextualization work.

\section{A Consolidated Approach to Glocalization: Contextualization Work}

Glocalization as Institutional Work. Institutional work has been defined as the 'purposive actions of individuals and organizations aimed at creating, maintaining or disrupting institutions' (Lawrence and Suddaby 2006, p.215). This concept is well suited to represent the transfer of an institutionally and culturally 'loaded' practice such as RI. First, it has been 
used to help explain the emergence of RI institutions such as the FTSE4Good in the UK financial marketplace (Slager, Gond and Moon 2012); second, it has proved pertinent to the study of activities involved in institutional boundary crossing (Zietsma and Lawrence 2010); and third, it has accounted for how actors deliberately engage in political, cultural and technical work to facilitate the (global) diffusion of new practices (Lawrence, Suddaby and Leca 2009; Perkmann and Spicer 2008). Integrating the cultural, political, and technical dimensions of actors' practices makes institutional work a relevant construct for our investigation of RI glocalization. We seek to advance this integrated approach one step further by addressing the specific types of work that actors employ to perceive and mobilize the contexts from which the practice is exported and into which it is imported.

Glocalization as Contextualization Work. In line with the socio-technical view on glocalization and actor-network theory, we assume that the context is not given a priori but that actions give the new practice its new context (Ansari et al. 2010; Latour 1996; 2005). Specifically, we argue that individuals can make a difference in a glocalization process through their practices - as Bruno Latour (1996, p.137) remarked:

A single context can bring about contrary effects. Hence the idiocy of the notion of "pre-established context." The people are missing; the work of contextualization is missing. The context is not the spirit of the times, which would penetrate all things equally.

Following Latour's (1996) view, actors' work is central to the success of an innovation, as it governs whether contextualization happens or not. We therefore propose to label as 'contextualization work' the kind of institutional work that supports the construction of relationships between a foreign business practice and the institutional contexts of its import and export settings. Contextualization work refers to the ways in which individuals proceed to disentangle and reassemble both the material and symbolic components of a business practice in order to facilitate its glocalization, and so illuminates why and how individuals choose to combine an imported business practice with one local practice or material object 
rather than another, and how the practice itself is transformed as a result. Since, in principle, multiple objects, practices and discourses are available for such recombination, individuals engage in reasoning and make particular choices during their contextualization acts. By enhancing the resolution of how and why individuals use, add or remove specific components of a practice they seek to import, we aim to increase the understanding of how business practices are glocalized. We also offer, through the double case study of RI glocalization presented below, a skill set that can help individuals engage in glocalization, whether of RI or of other business practices.

\section{RESPONSIBLE INVESTMENT AS A GLOCALIZED PRACTICE \\ Defining Responsible Investment}

In this paper, RI refers to a set of investment practices that, at different times and in different contexts, have also been labeled as 'ethical investment', 'socially responsible investment', 'sustainable investment' or 'conscious investing' (Sandberg et al. 2009). Although the RI label is subject to debate (Sparkes 2006), the practice can be defined as:

... a set of approaches which include social or ethical goals or constraints as well as more conventional criteria in decisions over whether to acquire, hold or dispose of a particular investment. (Cowton 1999, p.60)

Practically speaking, and regardless of cross-national differences (Eurosif 2010; Louche and Lydenberg 2006; SIF 2010), RI covers a variety of investment practices that can be conveniently clustered into three broad sets (Kurtz 2008; Louche 2004; Schueth 2003):

- screening that consists of selecting stocks to be included in portfolios based on exclusion criteria ('negative screening') or a 'best-in class' inclusion logic ('positive screening');

- shareholder engagement, activism or advocacy that consists in mobilizing the context and rules of corporate governance to influence corporate behavior directly in relation to extrafinancial issues, for instance through proxy voting (Schueth 2003); 
- community investment that aims at providing capital to people in low-income or at-risk communities. This last practice represents only a marginal amount of investment and is not always regarded as RI outside the US (Louche and Lydenberg 2006).

\section{RI Emergence and Diffusion}

Although some forms of investment related to religious practice may even have biblical origins (Schueth 2003), several authors consider the development of contemporary forms of RI to be a more recent phenomenon (Domini 1992; Markowitz 2007). Sparkes (2006, pp.4244) stresses that religious groups - such as the Methodists and the Society of Quakers - played pioneering roles in the emergence of such RI practices as negative screening or shareholder activism in the first half of the twentieth century in the US (Pioneer Fund in 1928) and subsequently in the UK (Pax Fund in 1961), in Sweden (Ansvar in 1965) and in France (Nouvelles Strategies 50 in 1984) (Louche et al. 2012).

Vogel (1978) dates the beginnings of RI as a tool for 'lobbying the corporation' to the late 1960s and early 1970s. He stresses the role in its development of such political protests and social movements as the anti-Vietnam war or the South African anti-apartheid movements (especially in the US and the UK) although social movements of this type seem to have played a less important role in the development of RI in other contexts such as France (Déjean et al. 2012; Giamporcaro 2004). From 1984 to 1988, investments in RI products in the US increased from US\$40 bn. to US\$400 bn. (SIF 2005), a trend that continued during the 1990s; by 2002, US RI assets amounted to about US\$2 trillion, approximately two-thirds of worldwide RI assets. In 2007, US institutions had US\$2.71 trillion in total assets under management that employed one or more of the three RI practices of screening, shareholder advocacy or community investing (SIF 2010).

Building on its roots within different countries, and subjected to the process of financial markets globalization, the practice of RI kept expanding across the western world in the 
1990s and reached virtually across the world in the early 2000s (Louche and Lydenberg 2006). Nowadays RI represents a sizable proportion of US and European investments; by 2010 an estimated $12 \%$ and $10 \%$ (respectively) of total assets under management in these markets was invested in some form of RI (Eurosif 2010; SIF 2010). The worldwide growth of RI has been sustained over the last 15 years, and has influenced mainstream investment through signaling the significance of social and environmental risk (Louche et al. 2012).

\section{Cross-National Variations in RI}

Despite the growing development and acceptance of RI practices across the globe, there remain important variations in RI definitions, developments, and practices in different countries. First, studies focused on specific countries have noticed that RI practices are usually connected to idiosyncratic aspects of local cultural, political or market environments. Sakuma and Louche (2008) noted that the role of religious groups in the emergence of RI in Japan has been non-existent, whereas Bengtsson (2008) illustrates their pioneering role in building RI in Scandinavian countries before the 1990s. According to Lozano et al. (2006), 'negative screening' became the dominant RI practice in Spain in the late 1990s, while RI practitioners in France or Italy followed a different path over the same period of time, focusing mostly on 'positive screening.'

Second, studies comparing RI across countries have noticed important variations in terms of market developments and dominant practices (Eurosif 2010) according to factors such as the organization of financial markets. For instance, Louche and Lydenberg (2006) suggest that shareholder activism through proxy voting requires the existence of market regulations similar to those in the US. RI practices are also influenced by the degree of local country governments' involvement in shaping RI markets (Bengtsson 2008; Eurosif 2010). In addition, RI practices are shaped by the cultural, religious and ideological orientations associated with the choice of terms used to describe RI ('sustainable' vs. 'ethical' investment) 
and the degree of specific categories of actors' and stakeholders' involvement in the development of RI practices (Sandberg et al. 2009). For instance, Guay et al. (2004) noted that NGOs played a key role in shareholder activism. The development of this RI practice may in a given country relate to the strength and strategies of its local NGOs.

This brief overview of RI development across countries suggests that RI provides a good illustration for the study of 'glocalized practices.' On the one hand, RI practices seem to be deeply grounded in the religious, cultural and social contexts in which they unfold, and so their form depends on the national institutional landscape (Bengtsson 2008; Domini 1992; Kurtz 2008). On the other hand, RI practices have become diffused globally, as evidenced by studies documenting their recent development in regions where they were absent only a couple of decades ago (e.g., Sakuma and Louche, 2008 for Japan). Even where RI practices are described as particularly idiosyncratic, authors have noticed the influence of such exogenous factors as European or US ‘models’ of RI (Sakuma and Louche 2008), 'responsible' financial indices (e.g., Dow Jones Sustainable index or FSTE4Good) (Lozano et al. 2006) or European and global institutions' promotion of RI (e.g., UN Principles for Responsible Investing) (Bengtsson 2008).

To explain the global diffusion of RI practices and the simultaneous growth of idiosyncratic local specificities, we focus on how actors' practices have supported the import of the US RI model and its glocalization into other countries.

\section{METHODS AND DATA}

\section{Case selection}

To examine the notion of contextualization work in practice, we studied two cases in which entrepreneurial actors imported RI practice from the United States to France and to Québec. In terms of sampling for theoretical purposes (Yin 2009), these two receiving contexts reflect 
important political and cultural differences relative to the import context. United States is a liberal market economy (Hall and Soskice 2001) while France is a state-centered economy (Schmidt 2003) and Québec a coordinated market economy (Bourque 2000). Québec has considerable institutional autonomy within Canada, and applies an economic model that differs substantially from the liberal market economy of federal Canada. France and Québec also differ from the US from a religious viewpoint, both being traditionally Catholic rather than Protestant, which is important given the religious roots of RI (Sparkes 2006). We can expect that more contextualization work will be required where there are substantial discrepancies between the original and receiving institutional contexts. While extreme cases such as these are not statistically representative, they are ideal for theory building because they illuminate processes that are likely also to apply to less extreme cases (Yin 2009).

The first 'ethical fund' in France was launched in 1983 by Soeur Reille to manage the funds of a Christian religious community (Louche et al. 2012) while Québec has a long history of making social RI in its own economic development initiatives under various labels, notably that of 'social economy' (Neamtam 2005). Although early forms of RI existed in both France and Québec before the contextualization processes we studied, several indicators suggest that RI practice did not develop in either of these receiving contexts before the US RI practice was well established in the late 1990s (SIF 2005). For instance, RI terminology first appeared in New York Times in the late 1980s, while it did not appear in Le Monde (France) until 1999 and in La Presse (Québec) until 2000. ${ }^{\text {i }}$

France had 7 RI funds in 1997, 42 in 2001 and 118 in 2004 (Muet et al. 2002; Novethic 2004), with total RI assets growing from $€ 0.2 \mathrm{bn}$. in 1997 to $€ 3 \mathrm{bn}$. in 2004 , at a period when the French investment market was generally stagnant (Novethic 2004). The European RI market increased from $€ 2.7$ trn. in 2007 to $€ 5$ trn. by the end of 2009 , with France considered to be one of the leaders in terms of RI market growth (Eurosif 2010). In comparison, Canada 
had more than 30 ethical investment funds in 2002 (CPF 2002), and the RI market grew twice as fast as the Canadian mutual fund market as a whole, with total RI assets rising from approximately CA\$50bn. in 2002 (ibid) to CA\$65bn. in 2004 (Association Investissement Responsable 2005). As a province of Canada, Québec began to establish its own formal RI market around 2002. The time lag between the development of RI practices in the US and in France and Québec may explain why the entrepreneurs we identified in both receiving contexts regarded the 'US model' of RI as their main source of inspiration.

We conducted case studies on two initiatives to adapt RI to the local contexts in France and Québec respectively. The case study method is well adapted to our purpose of exploring contextualization (Yin 2009), as it can account for the uncertainty surrounding the innovative aspect of contextualization (Latour 1996; 2005). In the French case, the contextualization work undertaken by the entrepreneur whose actions we studied led to the creation of ARESE in 1997. The mission of this agency was to provide structured, quantified information to RI fund managers to help them select the most ethical or responsible companies for their investment portfolios. ${ }^{\text {ii }}$ ARESE was the first formal initiative in the French financial community to quantify and legitimize the notion of corporate social responsibility (Arjaliès 2010; Déjean et al. 2004; Igalens and Gond 2005).

In the Québec case, RI contextualization was the outcome of the entrepreneurial work of the founder of Fonds d'Investissement Responsable (FIR), a RI fund created in 2003. Its mission consisted in 1) evaluating the financial, social and environmental sustainability of small and medium sized enterprises (SMEs) in Québec and 2) using risk capital to make investments in the most promising companies. Half of this capital was provided by two labor union pension funds in Québec and the other half came from public environmental protection funds that had been transferred from a non-governmental organization. FIR, whose contextualizing of RI began in 2002, sought to develop an RI assessment tool that would 
foster sustainable development in the Québec economy.

Although the two cases of contextualization had different outcomes (a rating agency vs. an RI fund), in both cases the entrepreneurs involved followed similar paths in their contextualization work. This work involved translating elements from US RI practices to their own context and being confronted by similar practical issues such as the construction and definition of specific criteria to support local RI practices. In this regard, these two cases constitute 'comparable' cases (Détienne 2000), that allow us to observe the content of the contextualization process, which is our main research focus.

\section{Data collection}

Our main data source was interviews, which has been recognized as one of the best ways to capture individual perceptions and practices (Yin 2009). We first identified key individuals involved in importing RI into either of the two contexts; they included both internal firm members (e.g., the CEO, financial analysts, and board members) and external players (e.g., sustainable development managers of evaluated companies and managers of socially responsible funds and partnering organizations). The interviews inquired about their interests in implementing RI, their perceptions of the difficulties they encountered, and their strategies for overcoming such obstacles. In total, we conducted 24 semi-structured, retrospective interviews in the French case and 11 semi-structured, in-situ interviews in the Québec case. All interviews were tape-recorded and transcribed (see Appendix 1 for a list of interviewees).

In the French case, we conducted the interviews after ARESE had merged with Vigeo in 2002, which made it easier for interviewees to express themselves freely (Boiral 2000). In contrast, interviews in the Québec case were conducted at a politically precarious time for interviewees, so we protected the anonymity of informants and organizations by using proxy names. To validate our interview data through triangulation, we collected newspaper articles (French case), observed group meetings (Québec case), and consulted company reports (both 
cases), which allowed us to check the reliability of our interviewees' reports about RI practice contextualization.

\section{Data Analysis}

We conducted a three-stage data analysis process aimed at tracking the glocalization of RI practices and identifying the contextualization work that sustained the process of glocalization. First, we organized our process data to account for the longitudinal process of glocalization, adopting 'temporal bracketing' and 'narrative' strategies to make sense of it (Langley 1999, pp.694-697). Specifically, we built narratives that followed the steps of RI translation for each case (Guba and Lincoln 1994).

Second, we used these two narratives to identify practices aiming at 'glocalizing' RI, which we grouped into categories. We identified, in both narratives, all instances in which actors mentioned 1) either the former or the new practice context and 2) how the RI practice was related to either elements of the old or new contexts, or changed in relation to one of these contexts. Then we used open coding to group the practices we identified, and assigned a label to each group of practices to represent a specific type of contextualization work.

Third, to confirm and simplify our categorization of contextualization work, we recoded all the interviews to validate our initial repertoire of contextualization work (Miles and Huberman 1994). To avoid instances of post-rationalization in the retrospective (French) case, we verified that each type of work also appeared in the real-time data from the Québec case. The resulting repertoire of three types of contextualization work we identified - (1) Filtering work, (2) Repurposing work, (3) Coupling work - represents our core research finding. Table 1 defines these types and provides illustrations of each one.

INSERT TABLE 1 ABOUT HERE 


\section{CONTEXTUALIZATION WORK FOR RESPONSIBLE INVESTMENT}

The entrepreneurial individuals in the two cases we studied worked in different societal contexts and entertained different perceptions of US RI practices. Yet, they deployed the same three types of contextualization work to glocalize RI into their contexts, which we describe here and illustrate each with examples from both contexts.

\section{Filtering Work}

Filtering occurs when actors eliminate or downplay features of the imported practice that they fear may block its adoption in the new context. These features may be specific practices, material expressions, beliefs or values that carry negative connotations in the new context. Filtering serves to prevent the local context from blocking the adoption or implementation of the foreign business practice on account of these features. As in 'selective emulation' (Westney 1987), filtering identifies and disentangles discursive or material elements that may be perceived as illegitimate or unattractive in the local setting; actors in both France and Québec employed this type of contextualization work.

In France, one of the original features of the US RI construct that the contextualizing actors perceived as salient was its moral undertones of investing in something 'inherently good' as opposed to the comparative 'irresponsibility' of ordinary investments. In the French case, the future CEO of ARESE and the members of her support team relied on filtering to develop an evaluation tool for social investment in France because they feared that mainstream investors on the French market perceived the moral (and even religious) claims of RI with some suspicion. Before the formal creation of this evaluation tool, she had travelled to the United States and other European countries to deepen her knowledge of RI and evaluate its prospects in the French setting. She judged that some components of the RI practices that she encountered would be culturally incongruent with French culture:

I realized that the model was extremely militant... and really difficult to export. The model of [responsible] investment was marked by values directly inherited from 
puritanism or civil rights engagement. So, it was something really embedded in the American and Anglo-Saxon culture. On the religious side, it was the Quakers; on the civil side, it was related to the problem of minority discrimination and inspired by Martin Luther King; on the consumer side, it was Ralph Nader. So there were three leverages: racial leverage, religious and consumerist ... In these approaches, the evaluation method was not important, and this value-based legacy was really not exportable. On the contrary, the financial leverage of pension funds appeared very credible to me. (ARESE CEO)

Although racial, religious and consumer problems have also shaped French society at various times, they have not been expressed in quite the same way as in the US. In fact, such problems could not legitimately be expressed in France through the channel of financial markets. For instance, the future ARESE CEO was well aware of French religious investors' attempts to develop RI practice in France in the early 1980s. When preparing her project, she met with Sister Nicole Reille who had created the 'Ethics and Investment' association in 1983 and also launched 'Nouvelle Strategie 50', which was regarded as the first socially oriented investment fund in France. But, as only seven investors had embraced this religious perspective after ten years of operation, the future ARESE CEO saw this approach 'condemned [RI] to be a niche market.' From her perspective, some of these associations to moral and religious traditions in the United States needed filtering before entrepreneurs could hope to develop an RI evaluation tool that would be construed as legitimate and attractive on the wider French financial market. When preparing the ARESE business plan, she and her team carefully removed the overtly moral and religious elements in the US RI construct, highlighting instead the technical dimensions of corporate evaluation. They constructed a quantitative methodology that they believed would pass as 'morally neutral' in French society, an emphasis that resonated well with French investors and facilitated their acceptance of RI (Déjean et al. 2004). This filtering work also applied to the activist dimension of RI in the US, which she regarded as 'un-exportable' because it was closely related to the financial market regulations that enabled proxy voting in the US.

In striking contrast to the French context - where actors perceived the RI practice of the 
United States as 'too' moral or religious and not sufficiently business-oriented - the entrepreneurial actors in the Québec context regarded the US concept of RI as excessively profit-oriented. They expressed skepticism about the idea of creating synergy between profitmaking and social gains - simultaneously making profit from investments and producing societal benefits - which many RI advocates in the US had emphasized. In Québec society, profit-making and societal benefits are traditionally construed as being in opposition to one another. For historical reasons, the French-speaking population of Québec (who the actors referred to as 'Québécois') tended to associate profit-making with social oppression and the exploitation of unskilled workers in industrialized factories that (at least until the 1960s) had been primarily owned and managed by the Anglophone community. The entrepreneur engaged in contextualizing RI into the Québec setting explained the symbolic underpinnings of profit-making thus:

The reality of this country [Québec society] is that we, the Québécois, had no power, nor money, for that matter. There were priests, notaries, doctors and liberal professions who did, but the rest of us did not touch money. They were dirty. They served to exploit others. I felt that way myself when I was 10 years old and wanted to be a communist. Now, at 38, I tell myself, I want to take charge of money myself. (CEO of FIR)

Although the Québécois community made significant progress in terms of developing Québec as their own nation, not least during the Quiet Revolution of the 1960s, the opposition between profit-making and societal benefit remains emotionally imprinted in collective cognition. Accordingly, the presumed synergy between profit-making and societal benefits had to be filtered out if RI were to become attractive and meaningful in Québec society. So the entrepreneur sought to minimize the prominence of profit-making in the RI concept, and to make RI more legitimate by reformulating 'profit' as a 'resource for social development' as illustrated in this quote:

When this project starts to make money, the part of that money that belongs to the environmental organization will be reinvested in environmental groups and educational projects. The money we generate will sustain the survival of the environmental organization. (CEO of FIR) 
This subordination of profit-making to social goals fitted the collective spirit of Québec well, so this filtering rendered RI legitimate in the new societal context.

Both these examples show how actors' perceptions of the original practice led them to engage in filtering, playing down those components of RI that they deemed to hinder its adoption in their respective settings. Interestingly - despite the contexts having the French language in common - the entrepreneurs in these two cases pushed RI in radically opposite directions through filtering: downplaying its morality in France and downplaying its profit dimension in Québec. We can see this work as institutional innovation, as it contributed to reshaping the practice and meaning of RI for a specific local context. Thus ARESE's filtering work in France downplayed the shareholder activism component of RI that had developed in the US, although this same dimension of RI later came to appeal to other French entrepreneurs, such as the creators of the CFIE (Centre Français d'Information sur les Entreprises) or the FiR (Forum pour l'investissement Responsable) who both considered that this component of US RI practice was indeed 'exportable' to France.

\section{Repurposing Work}

Repurposing transforms the raison d'être of a business practice by altering its meaning or changing its use or area of application. The imported business practice is rendered more appropriate and desirable for the new local context when actors realign it with the shared values and beliefs of that context (Vaara et al. 2006; Zilber 2006), assign it a new rationale or apply it to a new area of practice (Boxenbaum 2006). Thus repurposing infuses a foreign business practice with a new symbolic energy, assigns it a novel purpose, and/or catapults it into a hitherto unrelated domain of practice.

The French case offers a striking instance of repurposing in the choice ARESE made to shift its methodology from negative to positive screening. Negative screening consists in identifying firms that make money in industries that are considered immoral (e.g. alcohol and 
tobacco) and encouraging investors to exclude such firms from their portfolios (Giamporcaro 2004). In contrast, positive screening identifies those firms in a given industrial sector that perform best according to a set of social and/or environmental criteria, and encourages investors to include them in their portfolios. Negative screening was dominant in the US and the UK in the late 1990s when ARESE actors engaged in their contextualization work (Louche and Lyndeberg, 2006). It is still the dominant methodology in the US today (SIF, 2005, p.8), reflecting the religious and political elements underlying RI in the US, which are also manifest in social movements to change corporate behavior and consequently society (Louche et al., 2012; Vogel, 1978).

When ARESE replaced negative screening with positive screening, its goal was to radically transform the meaning of RI by turning it from a 'moral device' into a 'managerial tool.' The agency's discourse thereafter always presented RI as a 'tool' for assessing extrafinancial performance to increase long term financial performance. As an analyst reported:

She [the Founder/CEO of ARESE] always told us: 'We cannot sell [RI] in the name of ethics, we have to sell it as a financial product.' This is a tool that will be put to use [to fulfill our] goal, [which] is to inform investors, not to convey ideological or moral convictions. (Analyst B, ARESE)

The previous employer of ARESE's founder/CEO, a native of the US who had been engaged in RI consultancy in California since the 1980s, confirmed this radical transformation of RI. Skeptical that positive screening could contribute much to the promotion of social change, he expressed the need for repurposing in the following words:

[I] had some arguments with [the future founder/CEO of ARESE] about the technical aspects, the methodology and even the general logic [of social evaluation] ... The problem comes from a very different view of what 'social' means in North America and in continental Europe, and also from the total absence of an affirmative action logic in France. (Consultant A, former employer of the ARESE CEO)

The contextualization work the French entrepreneurs engaged in - repurposing RI by replacing negative screening with positive screening - aligned RI better with the French context, enhancing its symbolic meaning and adapting the screening practice to the French 
context.

However, in Québec, RI was repurposed as new evidence that the economy could be organized in a way that was more humane than a liberal market economy. Globalization and liberal market forces are widely perceived in Québec as destructive forces, so the traditional societal stance is one of militant resistance, as the founder/CEO of FIR explained:

I'm scared that people will say that I'm corrupt because I'm not choosing resistance. When I presented the project to the board of the environmental organization of which I was in charge, one board member said he was not in favor of it. [When] I asked why, he [said] "..... because you buy into the establishment". He had strong principles on this. He is anti-globalization, anti, anti, anti. (CEO of FIR)

The CEO saw in RI an opportunity to demonstrate the viability of an alternative production regime: 'I want to make sure that the firms we finance represent a model of sustainable development at all levels, as much social as environmental and economic.' Her repurposing represented RI as an extension of the strategy adopted during the Quiet Revolution: a collective effort to appropriate tools that would help restore social order and economic autonomy to Québec. She reframed RI as an act of 'empowering people for a common social cause', asserting that 'abuse, lies and the exploitation of children make me really angry. I want to restore justice; I want to change the power balance,' echoing the ideology of the Quiet Revolution.

Perhaps more interesting yet, she also presented RI as a contemporary form of resistance, arguing that the World Summit on Sustainable Development, held in Johannesburg in August 2002 shortly before the launch of FIR, sought to introduce new practices like RI to prevent ultra-liberalist multi-national corporations from exploiting individuals and the natural environment. Repurposed to this end, RI became infused with tremendous symbolic value: it simultaneously represented a local anchor and an open door to the global stage.

\section{Coupling Work}

Coupling work consists in adding a new material, practice-related, symbolic or discursive 
component to the foreign business practice so as to facilitate its local acceptance. Actors engage in coupling when they integrate a legitimate and desirable element into the imported business practice, in the same way as 'hybridization' (Zeitlin and Herrigel 2000) and 'bricolage' (Duymedjian and Rüling 2010).

In France, the team that launched ARESE in the mid-1990s perceived threats to the development of RI in France. All our interviewees who had been employed at ARESE in its early development stages agreed that there was considerable uncertainty around RI in France in 1997 and 1998. In fact, a market study conducted by the founder/CEO before the agency's launch concluded that the French market was not yet ready for RI. To overcome this situation, the entrepreneurs engaged in 'coupling work' to link RI practice to well-established concepts and objects in the French context. The approach ARESE developed relied on elements that were familiar to French managers and that helped solve technical problems. Such elements as the European Framework for Quality Management (EFQM), the wellestablished principles of Total Quality Management (TQM), and a stakeholder model of the firm were used to construct a methodological tool for corporate social evaluation. The combination of RI with Total Quality Management and financial concepts facilitated the acceptance of RI in evaluated firms. Especially managers trained in TQM were supportive: some of them even used ARESE's questionnaires to design their own internal CSR policies:

Personally, I found the ARESE referential [RI evaluation tool] to be well designed. As the underlying framework of that approach was satisficing, we decided to use it! You can consider social rating to be an external constraint and adopt a compliance attitude by simply providing the requested information. But, we decided to adopt a positive attitude and use rating as a managerial exercise... So, we use the ARESE referential as an internal management tool. (Quality Management Director of CAC 40 bank)

Coupling with TQM allowed RI to be well adapted to French trends and traditions.

In the case of FIR in Québec, extensive coupling work was used to legitimize the concept of RI. One instance involved the FIR CEO combining RI with the Life Cycle Approach (LCA). The LCA technique, derived from engineering and environmental science 
developed by pioneering engineering firms in Québec in the early 1980s, offered a conceptual frame and a rigorous tool for calculating the level of pollution a product generates over its entire life cycle. Already familiar with this approach, the CEO of FIR saw it as a conceptual frame that was compatible with the RI practice she was adapting, and also a very useful tool for assessing investment applications:

I first heard about the Life Cycle Approach two years ago, but I did not explore it that much. Now I am facing a real problem because sustainable development is really huge. People tell me 'it can mean anything.' [...] I want to be able to explain why we say yes, why we say no [to applications for investment]. And the Life Cycle Approach is rigorous. It is a model and when you apply it, you definitely do sustainable development. You prevent problems. (CEO of FIR)

She subsequently introduced LCA as a technical measure in FIR's RI evaluation tool and hired LCA specialists to manage the rating. Coupling work was thus successful in adapting the imported RI practice to the local setting in Québec, as it had been in France.

\section{REVISITING RI GLOCALIZATION THROUGH CONTEXTUALIZATION}

Through our double case study, we identified three types of contextualization work that entrepreneurial individuals in each case used to import elements from US RI practice to fit the context of France and Québec respectively. Our study yields a number of insights into contextualization work, including the interplay of political, cultural and technical dimensions of institutional work in the process of glocalizing new practices, and in particular, the interaction of symbolic and material transformation of practices during glocalization.

\section{Accounting for RI Diffusion and the Maintenance of RI Divergences}

Our perspective accounts in part for the puzzling divergence that appears as RI diffuses globally. As the notion is associated with factors that are deeply rooted in various sociocultural contexts, it can hardly be thought of as traveling freely across the world. Actors identify and select RI practices from a specific context, and then transform the practices they import through different types of contextualization work in order to make them acceptable in 
their host society. Specifically, our approach offers a micro-level account of how and why some RI practices differ in the US, France and Québec (Eurosif 2010; SIF 2010). For instance, the same feature of the original practice (e.g., the implied causal link between RI and profit) can be either accentuated (as in the French case) or toned down (as in the Québec case) to facilitate the glocalization of RI in those localities. This finding illustrates how what is regarded as a threatening element in one context can be perceived as a success factor in another. Thus a tool that some actors in a specific US context designed to serve religious and political purposes later became a rational way to generate long term investment performance in France and a practice to enhance social emancipation and social economy in Québec.

In reference to the political economic view of glocalization (Hall and Soskice 2001), our cases suggest that the work of contextualization does not fully reproduce the local institutions; rather it may sometimes transform these local institutions through the changes it introduced in the imported practice. The adaptation of the new practice to a new institutional context may unfold as a more complex, open, and time-related process than we would normally expect. For instance, from the 'varieties of capitalism' perspective, French labor unions would have been expected to play a crucial role in regard to RI contextualization (Schmidt 2003). Yet, since ARESE's actors did not mobilize them during their contextualization work, they were almost completely absent from our case study. However, once RI practice became accepted in France (partly as a result of ARESE's contextualization work), Nicole Notat, the former head of a French labor union, took over the organization in 2002 and re-contextualized the entire RI project according to a logic that was more attuned to the traditional French form of capitalism (Zarlowski 2007). Hence, contextualization work may take an indirect path that sometimes endorses existing institutions and at other times rejuvenates or alters them. The glocalization process is less straightforward than the political economic view would usually have us believe. 
Future research could mobilize our repertoire to explore the glocalization of RI practices within and across countries over longer time periods. For instance, future works could seek to clarify whether and how the three types of contextualization work we have described account for on-going re-adaptations of a glocalized practice after its initial importation. Prior studies have started to document differences in RI practices across countries (e.g., Bengtsson 2008; Sandberg et al. 2009), yet little is known about the processes whereby actors deliberately engineer these differences through their contextualization work.

\section{Conceptualizing Contextualization Work}

A second contribution of this paper is to advance, by theory and analysis, the concept of contextualization work as a new type of institutional work that seems to have been neglected to date. First, as a useful complement to the concept of boundary work (Zietsma and Lawrence 2010), this type of institutional work allows us to better capture the processes whereby institutions cross borders in consequence of the purposeful decision of actors to import institutions from one context to another. Our paper addresses the calls for a better integration of actor-network and institutional theory made by Lawrence and Suddaby (2006) and Lawrence and Suddaby and Leca (2009). The notion of contextualization reflects actornetwork insights and so enriches our understanding of the activities players undertake to translate institutions from one context to another, highlighting their agency in this process.

Second, in combining institutional and actor-network perspectives, our study sheds light on the complementarities of political, cultural, and technical dimensions in the process of glocalizing a practice. Ansari et al. (2010) suggest that the lack of political, cultural, and/or technical fit between a practice and its host context may explain why practices are adapted as they are diffused. However, prior studies have not envisioned that the three dimensions we identify call for different types of contextualization work, and they also remain relatively silent on how actors engage with these dimensions. Our perspective suggests that actors may 
have to deal with all three dimensions simultaneously and, specifically, it explains how actors may need to transform a practice so as to improve its fit on these dimensions. For example, ARESE's shifting from negative to positive screening in the French case can be regarded as a way to solve a technical problem (i.e., the number of stock rated corporations in the French financial marketplace being too small to allow negative screening), a cultural threat (i.e., the US carrying out negative screening mainly on religious grounds) as well as a political problem (i.e., using the business-like approach to RI that reflects best-in-class screening to align contradictory stakeholder interests). The integration of these three dimensions in the notion of contextualization work consolidates insights from prior glocalization perspectives, while at the same time acknowledging their complementarity.

One limitation of our study relates to the very nature of the practice under scrutiny: RI has been relatively broad, ambiguous, and poorly defined (Schueth 2003; Kurtz 2008). However this ambiguity did not prevent actors in either studied case from adapting what they perceived to be a 'US model' of RI. The fact that actors from France and Québec reinterpreted some of the features of the 'US model' of RI in diametrically opposed ways suggest that RI is especially 'open' to actors to transform it both symbolically and materially through their contextualization work. Future research could consolidate or refine our findings by studying contextualization work in the case of more precisely specified practices.

\section{Bridging Symbolic and Socio-material Dimensions in Institutional Work}

A third insight of this study concerns the integration of symbolic and socio-material forms of glocalization into a repertoire of contextualization work. In our case studies, entrepreneurial actors disentangled and re-assembled selected elements in ways that fitted the new contexts. Our repertoire suggests the presence of a specific pattern of disentanglement/re-assembly in the work of contextualization. Each of the three types of contextualization work we identify can engage both material and symbolic dimensions of the imported practice simultaneously. 
The integration we propose escapes the previous dichotomy between the 'technical issues' and 'rhetorical packaging' of practice adaptation. In referring to both socio-technical and cultural views, our consolidated perspective allows for the interplay of symbolic and material dimensions that unfold as actors engage in contextualization practices. Future studies could explore further how actors integrate material and symbolic elements of social ratings, CSR auditing or CSR consultancy practices.

\section{CONCLUSION}

This study has examined the practices that sustained the glocalization of responsible investment in France and Quebec and illuminated the contextualization work deployed by actors importing the practice into new contexts. Our results showed how individuals fitted the practice of RI to these contexts using three types of contextualization work - filtering, repurposing, and coupling - and how, in so doing, they reshaped RI at the political, cultural and technical levels. Contextualization work bridges the individual and societal levels of analysis. Most importantly, it integrates material and symbolic dimensions in accounting for how individuals engage creatively with readily available material objects, practices, ideas and symbols to produce the kind of institutional outcomes that have been identified but not explained in previous research on institutional work. The repertoire of contextualization work we catalogue makes glocalization practices explicit, and can be used to explore how individuals promote the circulation of locally generated business practices across institutional boundaries. 


\section{REFERENCES}

Akrich, M., Callon, M. and Latour, B.: 2002, 'The key to success in innovation', International Journal of Innovation Management 6(2), 187-206.

Ansari, S. M., Fiss, P. C. and Zajac, E. J.: 2010, 'Made to fit: How practice vary as they diffuse', Academy of Management Review 35(1), 67-92.

Arjaliès, D.-L.: 2010, 'A social movement perspective on finance: How socially responsible investment mattered', Journal of Business Ethics 92, 57-78.

Association Investissement Socialement Responsable: 2005, 'Revue 2004 de l'investissement socialement responsable au Canada: Une enquête approfondie sur l'investissement responsable au Canada'. Available: www.socialinvestment.ca

Bengtsson, E.: 2008, 'A history of Scandinavian socially responsible investment', Journal of Business Ethics 82(4), 969-983.

Biggart, N. W. and Beamish, T. D.: 2003, 'The economic sociology of conventions: Habit, custom, practice, and routine in market order', Annual Review of Sociology 29(1), 443464.

Biggart, N. W. and Guillén, M. F.: 1999, 'Developing difference: Social organization and the rise of the auto industries of South Korea, Taiwan, Spain, and Argentina', American Sociological Review 64(5), 722-747.

Boiral, O.: 2000, 'Outside the iron cage', Organization Science 14, 720-737.

Bourque, G.: 2000, Le modèle québécois de développement: De l'émergence au renouvellement (Québec: Presses de l'Université du Québec).

Boxenbaum, E.: 2006, 'Lost in translation. The making of Danish diversity management', American Behavioral Scientist 48(7), 939-948.

Casper, S. and Hancké, B.: 1999, 'Global quality norms within national production regimes: ISO 9000 standards in the French and German car industries', Organization Studies 20(6), 961-985.

Committee of Public Finance: 2002, 'Corporate social responsibility and socially responsible investment'. Consultation document, National Assembly of Quebec, May. Available: http://www.assnat.qc.ca/eng/Publications/rapports/concfp1.htm

Cowton, C. J.: 1999, 'Playing by the rules: Ethical criteria at an ethical investment fund', Business Ethics: A European Review 8(1), 60-69.

Czarniawska, B. and Joerges, B.: 1996, 'Travels of ideas' In B. Czarniawska and G. Sevón (eds) Translating Organizational Change (Berlin: Walter de Gruyter), 13-48.

Déjean, F., Gond, J.-P. and Leca, B.: 2004, 'Measuring the unmeasured: An institutional entrepreneur strategy in an emerging industry', Human Relations 57(6), 741-764.

Déjean, F., Giamporcaro, S., Gond, J.-P., Leca, B. and Penalva, E.: 2012, 'Mistaking an emerging market for a social movement? A comment on Arjaliès' social-movement perspective on socially responsible investment in France', Journal of Business Ethics 112 (2), 205-212.

Détienne, M. 2000. Comparer l'Incomparable (Paris: Seuil).

Djelic, M.-L. and Quack, S.: (eds) 2003, Globalization and Institutions: Redefining the Rules of the Economic Game (Cheltenham, UK: Edward Elgar Publishing).

Domini, A.: 1992, 'What is social investing? Who are social investors?', In: P.Kinder, S. Lydenberg, and A. Domini (eds), The Social Investment Almanac (New York: Henry Holt), 172-179 
Duymedjian, R. and Ruling, C.-C.: 2010, 'Towards a foundation of bricolage in organization and management theory', Organization Studies 31(2), 133-151.

Eurosif: 2010, European SRI study. www.eurosif.org.

Fiss, P. and Zajac, E. J.: 2004, 'The diffusion of ideas over contested terrain: The (non)adoption of a shareholder value orientation among German firms', Administrative Science Quarterly 49, 501-534.

Frenkel, M.: 2005, 'The politics of translation: How state-level political relations affect the cross-national travel of management ideas', Organization 12(2), 275-301.

Giamporcaro, S.: 2004, 'L'investissement socialement responsable en France. Un outil au service d'une action politique par la consommation?' Sciences de la Société 62, 169-189.

Greenwood, R., Oliver, C., Sahlin, K. and Suddaby, R. (eds): 2008, The Sage Handbook of Organizational Institutionalism (London: Sage Publications).

Guay, T., Doh, J. P.and Sinclair, G.: 2004, 'Non-governmental organizations, shareholder activism, and socially responsible investments: Ethical, strategic, and governance implications', Journal of Business Ethics, 52(1), 125-139.

Guba, E. G. and Lincoln, Y. S.: 1994, 'Competing paradigms in qualitative research', In N. K. Denzin and Y. S. Lincoln (eds.), Handbook of Qualitative Research (London: Sage), 105-117.

Hall, P.A. and Soskice, D.: 2001, 'An introduction to varieties of capitalism', in P.A. Hall and D. Soskice (eds) Varieties of Capitalism: The institutional Foundations of Comparative Advantage (New York: Oxford University Press), 1-68.

Igalens, J. and Gond, J.-P.: 2005. 'Measuring corporate social performance in France: A critical and empirical analysis of ARESE data', Journal of Business Ethics, 56(2), 131148.

Jackson, G. and Deeg, R.: 2008, 'Comparing capitalisms: Understanding institutional diversity and its implications for international business', Journal of International Business Studies 39(4), 540-561.

Jacoby, W.: 2000, Imitations and Politics. Redesigning Modern Germany (Ithaca, New York: Cornell University Press).

Kurtz, L.: 2008, 'Socially responsible investment and shareholder activism'. In: A. Crane, A. McWilliams, D. Matten, J. Moon and D. S. Siegel (eds) The Oxford Handbook of Corporate Social Responsibility (Oxford: Oxford University Press), 249-267.

Langley, A.: 1999, 'Strategies for theorizing from process data', Academy of Management Review 24, 691-710.

Latour, B.: 1993, We Have Never Been Modern (Cambridge, MA: Harvard University Press).

Latour, B.: 1996, Aramis, or the Love of Technology (Cambridge, MA: Harvard University Press).

Latour, B.: 2005, Reassembling the Social. An Introduction to Actor-Network Theory (Oxford: Oxford University Press).

Lawrence, T. B. and Suddaby, R.: 2006, 'Institutions and institutional work', In: S. R. Clegg, C. Hardy, T.B. Lawrence, and W.R. Nord (eds.) Handbook of Organization Studies, (London, UK: Sage), 215-254.

Lawrence, T. B., Suddaby, R. and Leca, B. (eds.): 2009, Institutions and Institutional Work (Cambridge, UK: Cambridge University Press).

Le Monde: 1998, 'Concilier l'éthique et la finance', September 5, 14.

Louche, C., \& Lydenberg, S.: 2006, Socially Responsible Investment: Difference Between 
Europe and United States. Working Papers, Vlerick Leuven Gent Management School, series 2006-22.

Louche, C.: 2004, Ethical Investment. Processes and Mechanisms of Institutionalisation in the Netherlands, 1990-2002, Unpublished doctoral dissertation, Erasmus University, Rotterdam.

Louche, C., Arenas, D. and van Cranenburg, K. C.: 2012, 'From preaching to investing: Attitudes of religious organizations towards responsible investment', Journal of Business Ethics (published on line, forthcoming).

Lozano, J. M., Albareda, L. and Balaguer, L.: 2006, 'Socially responsible investment in the Spanish financial market', Journal of Business Ethics, 69(3), 305-316.

Markowitz, L.: 2007, 'Structural innovators and core-framing tasks: How socially responsible mutual fund companies build identity among investors', Sociological Perspectives 50(1), 131-153.

Miles, M. B. and Huberman, A.: 1994, An Expanded Source-book: Qualitative Data Analysis, (London, UK: Sage).

Muet, P.-A., Bayard, S. and Pannier-Runacher, A.: 2002, Rapport d'Enquête sur la Finance Socialement Responsable et la Finance Solidaire, Inspection Générale des Finances, N²001-M-044-01. Ministère de l'Economie et des Finances.

Neamtam, N.: 2005, 'The social economy: Finding a way between the market and the state', Policy Options July/August, 71-76.

Novethic: 2004, L'Indicateur Novethic. $1^{\mathrm{er}}$ trimester 2004. Available: www.novethic.fr

Özen, Ş. and Berkman, Ü.: 2007, 'Cross-national reconstruction of managerial practice: TQM in Turkey’, Organization Studies 28(6), 825-851.

Perkmann, M. and Spicer, A.: 2008. 'How are management fashions institutionalized? The role of institutional work', Human Relations 61, 811-844.

Pieterse, J. N.: 1994, 'Globalization as hybridization', International Sociology 9(2), 161-184.

Robertson, R.: 1992, Globalization: Social Theory and Global Culture (London,UK: Sage).

Sahlin-Anderson, K.: 1996, 'Imitating by editing success: The construction of organizational fields', in B. Czarniawska and G. Sevón (eds) Translating Organizational Change. Berlin: Walter de Gruyter, 69-92.

Sakuma, K. and Louche, C.: 2008, 'Socially responsible investment in Japan: Its mechanisms and drivers', Journal of Business Ethics 82(2), 425-448.

Sandberg, J., Juravle, C., Hedesstrom, T. and Hamilton, I.: 2009, 'The heterogeneity of socially responsible investment', Journal of Business Ethics 87(4), 519-533.

Schmidt, V. A.: 2003, 'French capitalism transformed, yet still a third variety of capitalism', Economy and Society 32(4), 526-554.

Schueth, S.: 2003, 'Socially responsible investing in the United States', Journal of Business Ethics 43, 1987-194.

Slager, R., Gond, J.-P. and Moon, J.: 2012, 'Standardization as institutional work: The regulatory power of a responsible investment standard', Organization Studies 33(5-6), 763-790.

Social Investment Forum: 2005, Report on Socially Responsible Investing Trends in the United States. Available: www.socialinvest.org.

Social Investment Forum: 2010, Socially Responsible Investment Trends in the United States. Available: www.ussif.org

Sparkes, R.: 2006, 'A historical perspective on the growth of socially responsible 
investment', In: R. Sullivan and C. MacKenzie (eds.) Responsible Investment (Sheffield: Greenleaf Publishing), 39-54.

Vaara, E., Tienari, J. and Laurila, J.: 2006, 'Pulp and paper fiction: On the discursive legitimation of global industrial restructuring', Organization Studies 27(6), 789-810.

Vogel, D.: 1978, Lobbying the Corporation: Citizen Challenges to Business Authority (New York: Basic books).

Westney, E. D.: 1987, Imitation and Innovation: The Transformation of Western Organizational Patternsto Meiji Japan (Cambridge, MA: Harvard University Press).

Whitley, R.: 1999, Divergent Capitalisms: The Social Structuring of Change of Business Systems (Oxford: Oxford University Press).

Yin, R. K.: 2009, Case Study Research: Design and Methods, fourth edition (Newbury Park, CA: Sage Publishing).

Zarlowski, P.: 2007, 'Marketing corporate social responsability in a national context: The case of social rating agencies in France', In: F. den Hond, F. de Bakker and P. Neergaard (eds) Managing CorporateSsocial Responsibility in Action: Talking, Doing and Measuring (Ashgate Publishing), 167-186.

Zeitlin, J. and Herrigel, G.: (eds) 2000, Americanization and its Limits. Reworking US Technology in Post-war Europe and Japan (Oxford: Oxford University Press).

Zietsma, C. and Lawrence,T.: 2010, 'Institutional work in the transformation of an organizational field: The interplay of boundary work and practice work', Administrative Science Quarterly 55, 189-221.

Zilber, T.: 2006, 'The work of the symbolic in institutional processes: Translations of rational myths in Israeli high tech', Academy of Management Journal 49(2), 281-303. 